\title{
Lansky Performance Status 100
}

National Cancer Institute

\section{Source}

National Cancer Institute. Lansky Performance Status 100. NCI Thesaurus. Code C69426.

Full active, normal. 